\title{
Keeping the Arctic 'Cold': The Rise of Plurilateral Diplomacy?
}

\section{- Article forthcoming in Global Policy $4 / 4$ (2013)-}

\author{
Dr. Corneliu Bjola \\ University Lecturer in Diplomatic Studies
}

\begin{abstract}
At the time when the Arctic region faces significant climatic transformations, a triple governance gap threatens to fuel major diplomatic tensions among regional actors over natural resources, navigation rights, and fishery management. The article argues that a plurilateral diplomatic approach could help close these gaps by establishing an effective "web of contracts" involving institutional networks defined around the Arctic Council as the central node of Arctic governance and NATO, the International Maritime Organization and UNDP/GEF as supporting agencies. In so doing, the article makes two important contributions to the literature on global governance. It explains how governance gaps could be closed in a manner that does not require extensive institutional frameworks or rigid legal mandates, and it launches a debate about the role on institutional networks in sustaining regional and global governance.
\end{abstract}




\section{INTRODUCTION}

Against the backdrop of steady environmental transformation, the situation in the Arctic is attracting increased diplomatic attention as issues of access, control, property rights and resource use are set to challenge the governance of the global commons in the Arctic The scramble for resources in the Arctic has already increased anxiety in the region: NATO sources are getting worried about the potential for armed conflict between the alliance and Russia (Jones and Watts 2011), Canada and Russia have been testing each other's resolve to defend their territorial claims in the Arctic (CBCNews 2010), the United States (U.S.) has been anxiously watching the Chinese diplomatic efforts to secure toeholds in the region (Rosenthal 2012), while the international race for resources in the frozen wastes of the Arctic has brought down the first national government of Greenland (Macalister 2013).

The empirical evidence showing that something serious is taking place climatically in the Arctic is becoming harder to scientifically refute and to politically ignore. According to the 2007 report of the Intergovernmental Panel on Climate Change (IPCC), "satellite data since 1978 show that annual average Arctic sea ice extent has shrunk by 2.7 [2.1 to 3.3]\% per decade, with larger decreases in summer of 7.4 [5.0 to 9.8]\% per decade" (IPCC 2007: 30). In line with the past decade's trend, the Arctic sea ice fell below four million sq. km (1.54 million sq. mi) on September 4, 2012, the smallest value since the start of satellite observations in 1972 (Rincon 2012). The results suggest the Arctic region may soon enter a new climate era, if it has not already done so. Climate modelling indicates the melting of the Arctic ice sheet is only a matter of when, not if. In fact, the Arctic could be icefree as early as the end of this decade (Leitzell 2011). While climate change in the Arctic is increasingly perceived to have important consequences for regional and international stability, the scope and magnitude of these consequences remain a point of dispute. For some, the economic and 
security implications of Arctic transformations are likely to be severe and could eventually lead to "armed brinkmanship" (Borgerson 2008: 71). For others, the Arctic governance framework is "strong and dynamic", able to cope with the challenges brought about by global warming without the assistance of an additional legally binding comprehensive treaty (Stokke 2011: 835-6). In an effort to make sense of these disputing claims and identify what needs to be done to keep the Arctic diplomatically "cold", this article argues that conventional solutions are ill-suited for closing the Arctic governance gaps and that a plurilateral approach could be instead much more beneficial. More specifically, the paper seeks to analyse the conditions under which the evolving diplomatic dynamic in the Arctic can be successfully managed by drawing on the complementary competences of other institutions such as NATO, the International Maritime Organization (IMO) and UNDP/GEF.

To this end, the article will pursue three lines of inquiry. The first section reviews the main sources of diplomatic friction generated by the changing climate of the Arctic, especially regarding the growing strategic competition among regional actors over natural resources, navigation rights, and fishery management. The second part examines the strengths and limitations of the current governance framework in addressing these tensions with reference to the Arctic Council and the United Nations Conventions on the Law of the Sea (UNCLOS). Based on that, the third section discusses how the governance gaps in the Arctic could be closed through the pursuit of three distinct strategies of plurilateral diplomacy involving NATO, IMO and UNDP/GEF. 


\section{STRATEGIC DRIVERS OF DIPLOMATIC COMPETITION}

\section{1. Natural resources}

The warming of the Arctic is opening up three different areas of potential diplomatic friction for regional (Arctic coastal states) and non-regional actors (Japan, China, South Korea): over natural resources, navigation rights, and fishery management. The first one is probably the most important as the region contains not only vast amounts of minerals, but also of oil and natural gas. The Arctic seabed holds about 13 percent of the undiscovered oil, 30 percent of the undiscovered natural gas, and 20 percent of the undiscovered natural gas liquids in the world (U.S. Geological Survey 2008). In addition to oil and gas, the Arctic region also contains abundant mineral resources such as nickel, copper, tungsten, lead, zinc, gold, silver, diamonds, manganese, chromium and titanium for an estimated value of \$1.5-2 trillion (Glasby and Voytekhovsky 2009).

From a diplomatic viewpoint, the key issue regarding the Arctic natural resources is their location.. It is estimated that approximately 84 percent of the undiscovered oil and gas occurs offshore (Kenneth J. Bird et al. 2008: 4). The warming of the Arctic Ocean facilitates access to these untapped natural resources, and many of them, especially in the Bering and Beaufort Seas, fall in geopolitically contestable locations (see Fig 1). The high costs to develop reserves in the region (around 50-100\% more than for similar projects in warmer regions) and the harsh environmental conditions have not deterred major oil companies such as Exxon, Shell, Rosneft and Cairn Energy from filing exploration plans and starting to drill in the region (US Department of Energy 2012). Undoubtedly, other companies from Europe or Asia are likely to follow soon in their footsteps, but in order for them to be able to do this successfully one important issue needs to be sorted out: who exactly has the rights to exploit these resources? 
Fig 1: Geographical distribution of discovered and undiscovered resources of oil and gas in the Arctic-Source

Fig 1: Geographical distribution of discovered and undiscovered resources of oil and gas in the Arctic-Source: Reichert (2009: 398)

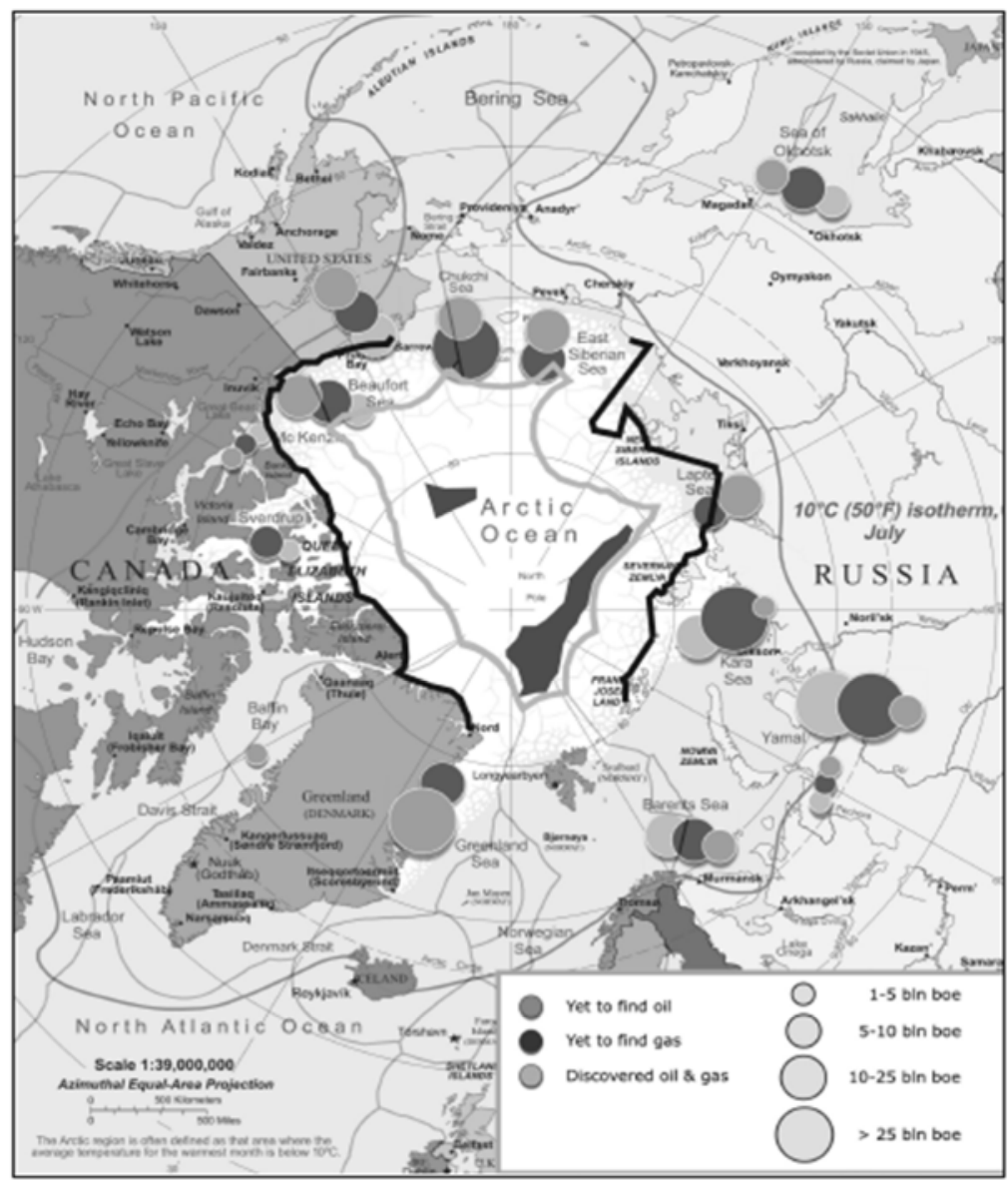

- The grey line denotes the outer limit of the Exclusive Economic Zone under conditions of Extended Continental Shelf

- The black lines denote the coastal baseline from which the breadth of the territorial sea is measured.

- The two grey patches denote the remnants of the Arctic Ocean that will not fall under national jurisdiction under the above condition.

- The filled circles denote locations of discovered oil \& gas and yet-to-be-found oil $\&$ gas.

Under the terms of the 1982 United Nations Law of the Sea Convention (UNCLOS), coastal states have the right to establish exclusive economic zones (EEZ) up to 200 nautical miles from their coastal baseline, within which they can exercise their "sovereign rights for the purpose of exploring and exploiting, conserving and managing the natural resources" (United Nations 1982: Art 56a). These rights may be further extended up to a maximum of 350 nautical miles if a country can 
demonstrate the seabed is a "natural prolongation" of its continental shelf (Art 76). Upon ratification of UNCLOS, a country has ten years to make a claim to extend its 200 nautical-mile-zone miles by submitting supporting scientific and technical data to the Commission on the Limits of the Continental Shelf (CLCS) (Annex II, Article 4). Thus far, Norway and Russia have made such submissions, but Canada and Denmark are also in the process of delineating the outer limits of their continental shelves. Russia is staking a claim, for instance, all the way to the North Pole along the Lomonosov Ridge, while Norway is laying claim to three separate areas in the North East Atlantic and the Arctic (Jares 2009: 1284, 1292).

On the positive side, the vast majority of the oil and gas resources in the Arctic fall within the EEZ of the coastal countries (see Fig 1) and hence no diplomatic frictions are expected to follow from this. Legal disputes may stem, however, from competing claims over the extension of continental shelves. Several of them are ongoing such as that between the United States and Canada in the Beaufort Sea, between Canada and Denmark over the maritime border of the Hans Island, and between Canada and Russia over the resource-rich underwater Arctic mountain range, the Lomonosov Ridge. The UNCLOS framework provides an appropriate instrument of dispute settlement for most of the Arctic coastal countries, with the exception of the United States, which has not yet ratified the treaty. This means that the U.S. cannot submit claims to the CLCS for the extension of its continental shelf. It can neither use the authority of UNCLOS for settling EEZrelated disputes, although it takes the view that most of the Convention provisions are already part of customary international law. 


\subsection{Navigation rights}

A second driver of diplomatic competition relates to the navigation rights along the new transportation routes to be opened up by the melting of the ice sheet. Shorter shipping routes through the High North will soon be available due to ice-free summers in the Arctic (see Fig 2). For instance, ships traveling from Yokohama to Rotterdam will reduce the journey by 35 percent if traveling via the Northeast Passage (along the Arctic coast of Russia) instead of the traditional southerly route through the Suez Canal. Similarly, the maritime journey between East Asia and Western Europe would take about 13,600 km using the Northwest Passage (crossing Canada's Arctic Ocean), while taking 24,000 km using the Panama Canal (Rodrigue 2012). However, the transformation of the Arctic into a global trade route would much depend on how concerns over schedule unreliability, draft restrictions and shipping infrastructure would be addressed in the coming years (Humpert and Raspotnik 2012).

With trade between Europe and Asia accounting for almost 20 percent of the global container trade volume in 2010 and the possibility of container traffic from North Asia through the Arctic becoming more economically attractive than through the Suez Canal as early as 2030 (Eide, Eide, and Endresen 2010), it comes as little surprise that China, South Korea and Japan have taken a keen diplomatic interest in becoming part of the governance of the Arctic trading routes. Their overall strategy thus far has been two-pronged. On the one hand, they have stepped up their commercial and scientific presence in the Arctic via newly commissioned icebreakers, the launching of Arctic-tailored satellite navigation systems and the establishment of research stations in the region. On the other hand, they have been intensifying their diplomatic efforts to become permanent observers to the Arctic Council the intergovernmental forum that promotes cooperation among the Arctic states (see more details below). 
Fig 2: Transportation corridors in the Arctic - Source: Eger (2011: 4)

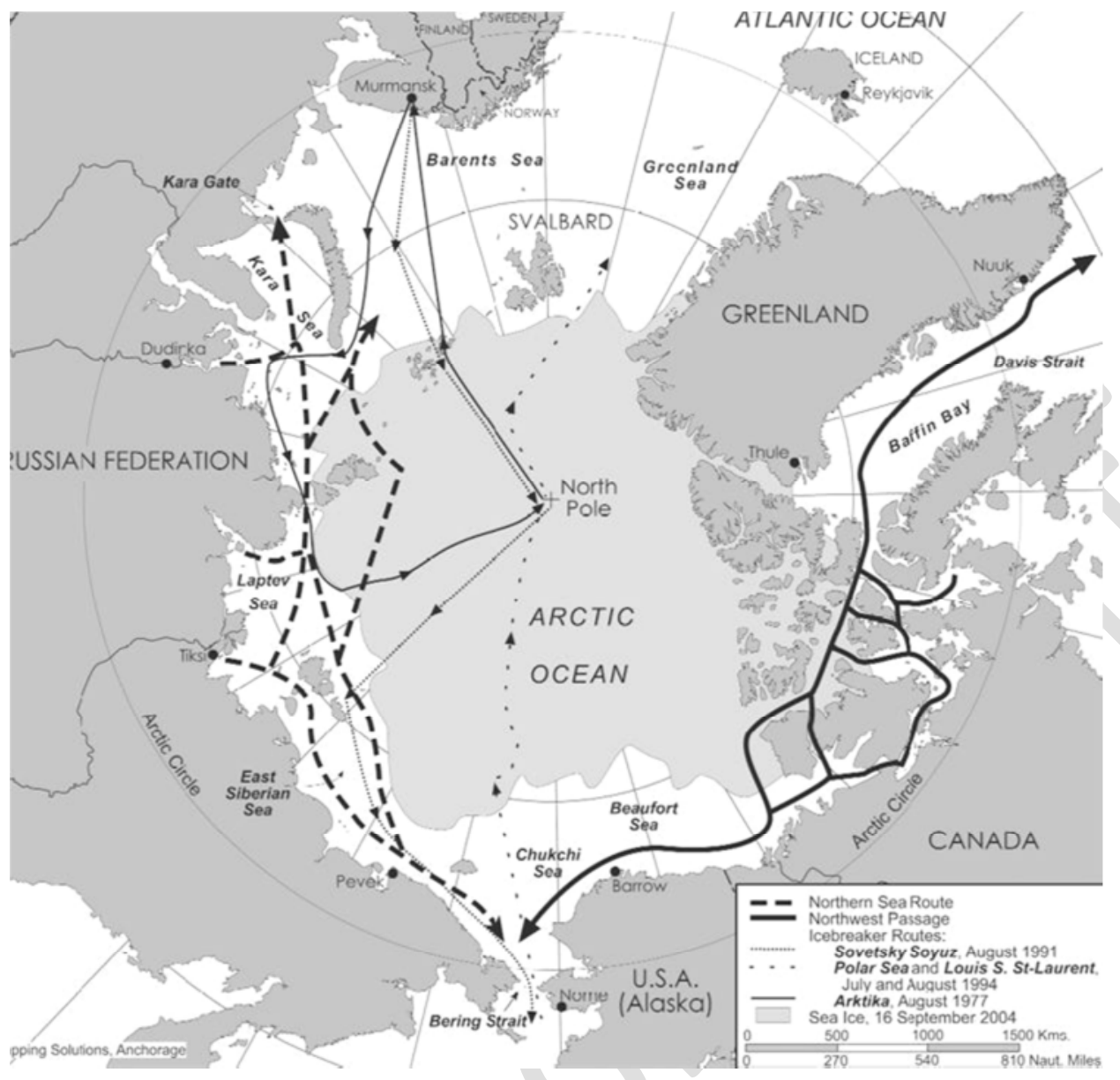

An important question for those who stand to benefit from the new transportation routes is whether their ships will have rights of transit vs. innocent passage though the straits of the Northwest and Northeast Passages. According to UNCLOS, transit passage "applies to straits which are used for international navigation" (Art 37). Innocent passage, on the other hand, refers to "navigation through the territorial sea" (Art 18). Unlike the rights to transit passage, which cannot be impeded or suspended, the rights to innocent passage can be restricted if ships are deemed to engage in activities that are "prejudicial to the peace, good order or security of the coastal State" (Art 19; United Nations 1982). The U.S. supports, for instance, the position that the channels in the archipelagos that form 
part of the Northwest and Northeast Passages qualify as straits used for international navigation, whereas Canada and Russia view them as internal waters and hence subject to their sovereign control. There is also the suspicion that coastal states might apply high fees for navigating through their straits under the clout of Art 234 of UNLCOS, which enables them to establish higher standards for vessel-source pollution. 2.3. Fishery management

A third important driver of diplomatic competition involves fishery management. The total catch of fish in the Arctic in 2002 amounted to around ten per cent of the world catch of wild marine fish (Lindholt 2006: 36), but this number is surely going to increase once the melting of the ice sheet will extend the length of the season and the geographical scope for fishing in the region. While the share of the Arctic in global fisheries remains low, it nevertheless represents an important resource for the coastal states. The Bering Sea supplies, for instance, a third of Russia's and a half of the US' total annual fish catch, while fishing in the Barents Sea is Norway's second largest earner of foreign exchange (Conley and Kraut 2010: 5).

On the positive side, the areas in the Arctic Ocean where substantial fishery activities take place are already covered by regional fisheries management organisations (RFMO), which are mandated under the 1995 UN Fish Stocks Agreement (FSA) to ensure the effective conservation and management of straddling and highly migratory fish stocks. The major challenges in fishery management in the Arctic stem, however, from three sources: lack of regulatory protection for the Central Arctic Ocean; illegal, unreported and unregulated fishing; and the uncertainty of the impact of new fishery on the marine environment and the Arctic communities (Hoel 2009: 452). These concerns have led the US Department of Commerce to approve a plan that would prohibit commercial fishing in an area covering nearly 200,000 square miles north of the Bering Strait. The pressure has thus shifted to other Arctic states, including Russia, Canada, Norway and Denmark, to follow suit and work 
together to develop a sustainable fishing plan that would protect the fragile and poorly understood ecosystem of the Arctic.

In sum, the melting of the Arctic ice sheet raises concerns over potential disputes involving the extension of continental shelves, stirs apprehension regarding the freedom of navigation, and prompts environmental and social concerns over the impact of fishing in the region. What needs to be also clarified is whether the existing governance framework in the Arctic can effectively address these issues, and if not, how these governance gaps can be closed? 


\section{THE ARCTIC GOVERNANCE FRAMEWORK}

Established in 1996,the Arctic Council (AC) has become the primary institutional mechanism through which governmental and non-governmental actors collectively address Arctic affairs. Its objective, as stated in the foundational Ottawa Declaration, is to serve as a "high-level forum to provide a means for promoting cooperation, coordination, and interaction among the Arctic States[and] Arctic indigenous communities [...] on common Arctic issues, in particular issues of sustainable development and environmental protection in the Arctic" (Arctic Council 1996). AC membership is comprised of three types of actors: representatives from the eight Arctic countries (Russia, Canada, US, Norway, Denmark, Finland, Sweden, Iceland), Permanent Participants (six indigenous organizations), and observers (representatives from non-Arctic states ${ }^{1}$, intergovernmental and inter-parliamentary organizations, global and regional, and non-governmental organizations that the Council determines can contribute to its work).

With its fairly rigid mandate focused on environmental protection and sustainable development, the Council's activities are conducted in six working groups composed of representatives of AC Member States and Permanent Participants. Occasionally supported by Task Forces appointed at Ministerial meetings to work on specific issues for a limited amount of time, AC working groups are tasked with conducting environmental research and advancing sustainable development measures for Indigenous Peoples and Arctic communities (Arctic Council 2012b). For example, under the Council's authority, the Arctic Climate Impact Assessment (ACIA) was carried out in 2000-2004 to assess the status of knowledge and develop scenarios of future climate change in the region (Berner et al. 2005). AC is prohibited from discussing security issues and its lack of legal authority hinders its capacity to

\footnotetext{
${ }^{1}$ As of Dec 2012, France, Germany, The Netherlands, Poland, Spain, United Kingdom have acquired the status of observers; China, Italy, Japan, South Korea, Singapore, India, European Union are currently applying for observer status (Arctic Council 2012a).
} 
negotiate multilateral treaties. However, in 2011, the Search and Rescue Agreement became the first legally binding agreement negotiated under the auspices of the Arctic Council.

As Permanent Participants, indigenous peoples' organizations contribute to the AC's mission in two ways: functionally and normatively. Indeed, according to the Council's protocol, permanent participants have "full consultation rights in connection with the Council's negotiations and decisions" since they "represent a unique feature of the Arctic Council and they make valuable contributions to its activities in all areas" (Arctic Council 2012). Representing what some term “indigenous diplomacy" (Loukacheva 2009: 52), the six indigenous organizations thus negotiate at the same table with the Arctic states, though without voting rights. On equal footing, they can submit statements alongside states, attend discussions in Ministerial Meetings, and serve as research partners in AC Working Groups. The "permanent participant" status of indigenous peoples arguably serves to legitimize AC as an international body genuinely representative for the region's inhabitants. Indeed, the special relationship with the indigenous populations is often included in the AC officials' discourse (George 2012), and by extension it reflects an important facet of the AC ideological profile. However, despite their deliberative and normative contributions, indigenous peoples' organizations remain constrained as they are not considered political entities with independent or collective legal personality. (Tennberg 2010: 268).

The current AC institutional structure, legal mandate, and level of political commitment offer, however, few incentives to its members to settle their differences within its framework, rather than outside it, are rather weak. Three root causes account for this. First, AC faces a significant institutional gap in dealing with these challenges. As pointed out by Koivurova, AC is a body that produces, via its working groups, non-binding technical guidance, scientific assessments and fairly abstract policy recommendations. (Koivurova 2010: 148). As a result, AC presently has no authority 
to take any position on matters involving territorial claims in the Arctic and enjoys only limited competences concerning navigation rights or the fishing regulatory regime of the Arctic Ocean

Second, AC is also vulnerable to the regulatory gap in the international and regional legal framework that covers Arctic matters, especially with respect to commercial shipping and fishery management. In its final report, the Arctic Governance Project (AGP) acknowledged, for instance, the importance of strengthening the regulatory framework on these matters. (Arctic Governance Project 2010: 8). However, in order for AC to achieve this, strong political will is required from its member states. AC faces a third and serious political gap in the level of interest and commitment of the members to extend the legal mandate of the Council and strengthen its institutional structure. The 2008 Ilulissat Declaration made clear, for instance, the five Arctic coastal states (Canada, Denmark, Norway, Russia and United States) saw "no need to develop a new comprehensive international legal regime to govern the Arctic Ocean" (Arctic Council 2008: 2). These gaps do not bode well for the future of the organization. If the situation persists, then parties may seek alternative solutions to pursue their interests, either in bilateral or unilateral terms, which are likely to fuel rather than defuse diplomatic tensions in the region. 


\section{PLURILATERAL DIPLOMACY}

If the Arctic Council is to survive as an institution, it needs, by necessity, to adapt One possible way to accomplish this is by building an international regime complex for the Arctic. As Young points out, a collection of three or more interactive arrangements related to each other in a non-hierarchical manner (i.e., a regime complex) could well emerge as a realistic alternative for addressing the Arctic governance needs (Young 2012: 392-3). UNCLOS and the Arctic Council already provide the foundational elements of this regime complex, but resource development (e.g., mining, oil and gas) or maritime issues could represent the next building blocks (Young 2012: 396). The regime complex idea invites, however, some important questions, which Young has failed to clarify: what kind of regime complex is actually needed in the Arctic, how exactly to build it, and equally important, how to make it work? This article argues the concept of plurilateral diplomacy offers an innovative and coherent framework for thinking about and addressing these questions.

This is so because AC possesses a critical asset the diplomatic potential of which has not been fully harnessed thus far: it provides an institutional platform for like-minded actors from inside and outside the region to develop common positions, which they can then advance in bilateral or multilateral contexts. In other words, it offers an excellent framework for the conduct of plurilateral diplomacy (Bayne and Woolcock 2011: 9). Unlike regional arrangements that give access to the governance of the region only to local actors, plurilateral forms of cooperation cut across geographical areas and allow non-regional actors to come together to discuss matters of common interest (e.g., OECD, G8/G20, the Commonwealth). However, unlike multilateral agreements that are characterized by a higher level of complexity due to the greater number of parties, issues, and time frame involved (Zartman 1994), plurilateral initiatives are limited to a reduced number of actors and the issues discussed are rather narrow in scope. Most importantly, the essence of the plurilateral 
diplomacy is that the very diffusion and decentralization of decision-making, rather than leading to instability, actually strengthens the resilience and adaptability of the international order by creating a "web of contracts" informed by overlapping memberships and cross-cutting interests (Cerny 1993: $49,51)$.

The advantages of plurilateral diplomacy for addressing the governance gaps in the structure of the Arctic Council are not to be ignored. Plurilateral diplomacy may offer a conduit for Asian countries like China, Japan or South Korea to take part in selective areas of governance of the region (e.g., transportation) alongside the Arctic coastal countries. At the same time, it could provide AC members a platform for seeking preliminary resolutions to territorial disputes or fishing rights without duplicating or undermining existing legal regimes, such as UNCLOS or RFMOs. Most importantly, plurilateral diplomacy would allow parties to circumvent the challenge of negotiating a new comprehensive international legal regime to govern the Arctic Ocean, an issue which, as pointed out above, was expressly opposed by the five Arctic circumpolar nations in the 2008 Ilulissat DeclarationIn short, plurilateral diplomacy can maximize the incentives for AC members to resolve their differences within its framework, rather than outside it. The "secret" to accomplishing this is by developing an institutional framework that would allow parties to reduce transaction costs, share critical resources, exchange know-how and facilitate implementation of agreements.

To accomplish this, the network of plurilateral agreements between AC and relevant institutions has to be carefully designed. First, the size of the plurilateral network is critically important. While the Arctic faces a multitude of challenges ranging from military competition to environmental degradation, it is important to focus, at least in the first stage, on establishing a minimal set of plurilateral connections, namely those that can effectively address the most pressing governance gaps in the region. An overextended plurilateral network would likely have the opposite result. The added 
bureaucracy and complexity of four or more plurilateral connections would have diminished return value for AC effectiveness. It is also important to start negotiating plurilateral agreements that deal with the least controversial issues (e.g., freedom of navigation or fishery management) and to use the eventual success and momentum for addressing the hard cases (e.g., territorial claims). A possible failure of plurilateral diplomacy in the early stages would likely reduce parties' interest and willingness to engage in similar actions.

Second, the distributional impact of the plurilateral agreements to be negotiated has to be properly assessed and taken into account. The impact evaluation pertains to two levels. On the one hand, the parties who have the power to create competing institutional arrangements to AC have to be closely involved in its work. At the moment, these refer to the US, Russia, China and the EU, as these actors have currently the capacity to engage in bilateral or multilateral negotiations that can diplomatically marginalize AC. On the other hand, there is the difference of status between AC member states, permanent participants and observers. While some Arctic coastal states have occasionally demonstrated an unfortunate disposition to engage permanent participants and observers only rhetorically, plurilateral diplomacy should nevertheless be conducted in such a way as to minimize further divisions between the various categories of AC members. This is important since the entire legitimacy of AC has been built around its capacity for dialogue, inclusiveness and cooperation.

Third, the plurilateral agreements concluded under AC umbrella should complement not duplicate or undermine the existing legal regimes overseeing international settlement of territorial disputes, navigation rights and overfishing regulations. The purpose of plurilateral diplomacy is not to develop comprehensive regulatory frameworks, but to offer a higher degree of specialization in a particular policy area and, at the same time, to allocate political resources on those objectives that are likely to be reached (Saner 2012: 26). Plurilateral diplomacy thus serves to enhance voluntary cooperation by 
allowing parties to decide for themselves what regulatory framework to join and to what extent. Furthermore, transparency is essential to this process. As Mitzen argues, the act of governing together requires parties to publicly share authority over their joint actions by providing them with the information necessary for staying engaged in the process: what the plan is, what does it entail, who is part of it, and how is each participant following through? (Mitzen 2010: 59). By contrast, lack of transparency undermines the parties' confidence in each other's actions and by that the very purpose of plurilateral diplomacy to enhance the voluntary cooperation among AC members would be compromised. These conditions could be most successfully met if AC establishes plurilateral connections with NATO, IMO and UNDP/GEF. 


\section{ARCTIC PLURILATERAL DIPLOMACY}

\section{The NATO Plurilateral Connection}

Military competition in the Arctic is a real possibility, not an overstated speculation. The National Security Presidential Directive (NSPD-66), issued by President G.W. Bush shortly before leaving office in Jan 2009, stated that the U.S. has "broad and fundamental national security interests in the Arctic region and is prepared to operate either independently or in conjunction with other states to safeguard these interests" (Bush 2009). Under President Obama, the US Navy made public its first Arctic "road map" to guide its policy, strategy and investments in the Arctic (US Navy Department 2009). In September 2008, Russian President Medvedev stated that the Arctic held "great strategic meaning" and the region was directly linked to the country's competitiveness in global markets" (Kilner 2008). Soon thereafter, the Russian Defence Minister announced that two Arctic brigades would be established in "Murmansk or Arkhangelsk or some other place", as early as 2015 (Debabov 2011)

In July 2009, Canada released its "Northern Strategy", which took aim at strengthening the country's "Arctic sovereignty" through "significant investments in new capabilities" and modernizing the forces responsible for providing military presence and surveillance in the region (Government of Canada 2009: 10). In the same fashion, the Danish Parliament approved a plan, in July 2009, to set up an Arctic military command and task force by 2014 (BBC 2009), while Norway declared the High North the "most important strategic priority area" and moved northwards the focus of the Armed Forces' resources and activities (Norwegian Ministry of Foreign Affairs 2011: 19).The military build-up in the Arctic is, arguably, tantamount to regional actors casting a vote of non- 
confidence in the capacity of the Arctic Council and UNLCOS to manage the challenges facing the region as a result of climate change.

A plurilateral diplomatic approach involving NATO may help reverse this trend. First and most importantly, NATO has a successful track record of conducting plurilateral diplomacy (Bjola 2002). Since the end of the Cold War, the Alliance has developed plurilateral connections with 41 countries (including Russia) through a variety of collective agreements. In addition, the Alliance pursues plurilateral cooperation in specific areas with a number of international and non-governmental organisations, including the African Union, the the International Organization for Migration, or the Organization for the Prohibition of Chemical Weapons. The fact that by December 2012, 24 nonNATO countries were contributing over 7000 troops to NATO-led operations (NATO 2013), speaks well of the capacity of the Alliance to promote international stability through plurilateral engagement.

Second, NATO is a regional player. Fifty percent of the circumpolar region belongs to NATO members and four out of five Arctic coastal states, excluding Russia, are NATO members. Third, NATO has already a strong militarily presence in the region. The Cold Response exercise conducted annually in the past six years by NATO in northern Norway has become the largest military exercise in the High North since the end of the Cold War (Norwegian Armed Forces 2012). Fourth, NATO possess the informational, technological and transportation capabilities to map the seabed, study weather patterns, ensure security of the transportation routes, conduct search \& rescue $(\mathrm{S} \& \mathrm{R})$ operations and monitor the effects of climate change in the region

In other words, NATO has the necessary logistics, experience and know-how to engage in plurilateral diplomacy and to prevent the militarization of the Arctic, but it has to tread carefully. 
Russia does not favour NATO involvement in the region (Chistyakov 2010), while Canada feels NATO military presence could exacerbate tensions and allow non-Arctic members to exert influence in an area where "they don't belong” (Clark 2012). However, NATO can constructively assist the stability in the Arctic by emphasising its diplomatic rather than its military dimension. The way to achieve this is by granting NATO the status of observer to the Arctic Council with the role to offer counsel on technical matters involving the security of the high-seas, such as the implementation of the recently adopted S\&R agreement or of similar arrangements. This move will present several important advantages. As an observer member, NATO would not have any voting rights, a fact that would placate the concerns of those who prefer not to grant the Arctic Council decision-making competences over security issues. While, as a matter of principle, Russia would resist NATO involvement in managing the security of the Arctic, it would likely prefer to have a say in how NATO conducts itself in the region as opposed to watching its actions from the sidelines.

NATO transparent participation in the work of the Council would help discourage military competition through joint surveillance, monitoring and confidence-building measures. NATO would play no role in settling legal disputes regarding the extension of the continental shelves, but its presence would indirectly increase the confidence of the parties in each other's willingness to comply with the provisions of UNCLOS. Equally important, NATO involvement as an observer in the structure of the Council would allow different international regimes to intersect (NATO, the Arctic Council, UNCLOS) in a manner that reinforces each other's strengths as governancedelivering bodies (security, institutional, and legal respectively), without any loss for their autonomy and in the absence of formal mechanisms of compliance. 


\section{The IMO Plurilateral Connection}

The competence for the regulation of global shipping lies with the International Maritime Organization (IMO), which is a specialized agency of the United Nations (UN) responsible for measures to improve the safety and security of international shipping and to prevent marine pollution from ships. (IMO 2011). Thus far, IMO has adopted around fifty treaty instruments and hundreds of other measures such as protocols and guidelines including for the Arctic. In 2009, IMOapproved revised Guidelines for ships operating in polar waters,and it is currently developing a draft international safety code (IMO 2013). . While the Guidelines have the character of recommendation, the Polar Code is supposed to create mandatory standards of maritime safety and pollution prevention.

In addition to IMO regulations, UNCLOS also includes provisions, under Art 234, for the prevention, reduction and control of marine pollution from vessels in ice-covered areas within the limits of the exclusive economic zone. It should be noted, however, that Art 234 must be read together with other UNCLOS provisions according to which coastal states should abide by international rules and standards adopted by IMO in matters of safety of navigation and prevention of marine pollution from ships. In other words, any laws to be adopted by coastal States in accordance with Article 234 should neither contradict nor overlap with IMO shipping rules and standards (Blanco-Bazán 2009: 384). This is important as it implies that the rights to innocent passage and the transit fees for navigating through Arctic straits cannot be arbitrarily suspended and applied respectively by the coastal states. The possible attempts of Russia and Canada to exert control over the waterway through bureaucratic measures (e.g., by requiring shippers to seek permits and submit their vessels to inspection), would therefore have a weak legal basis under UNLCOS and IMO guidelines. 
However, as IMO polar guidelines are not obligatory for member states and the outcome of the Polar Code negotiations remains uncertain, there is clearly space for improvement. An IMO plurilateral connection to the Arctic Council should be able to do just that. To date, sixty three intergovernmental organizations such as the African Union, the European Commission, or the Organization of American States have signed agreements of co-operation with IMO By becoming an observer member to the IMO, AC could better improve policy coordination among its members in two critical areas of governance. On the one hand, it could help monitor and enforce existing or future IMO navigation guidelines and standards for ships operating in polar waters. This is important as it could alleviate concerns about potentially abusive applications of UNCLOS provisions. On the other hand, as the volume of shipping in the region is expected to increase, AC would have the opportunity to take a more active part in shaping future IMO protocols and regulations concerning the security of navigation in the Arctic and the prevention of marine pollution. In sum, the AC-IMO plurilateral connection would offer a transparent diplomatic channel by which Arctic and non-Arctic states could coordinate efforts to improve the navigation in the region in a manner that mutually reinforces the authority of the two organizations.

\section{The UNDP/GEF Plurilateral Connection}

The question of Arctic fishing could be addressed, in principle, through a new regional fisheries management arrangement to be negotiated by regional actors under the auspices of the 1995 UN Fish Stocks Agreement. There are serious concerns, however, that such a RFMO would fail to take into account the full complexity of the environmental and social consequences to be induced by fishing in conjunction to activities related to infrastructure development, shipping and the exploitation of 
natural resources. In other words, a more holistic approach is required, the so-called EcosystemBased Management (EBM) method, to ensure ecosystem conservation and sustainable development in the Arctic (Siron et al. 2008: 87). The idea is that EBM could create protocols for shipping and resource development, establish a network of marine protected areas throughout the Arctic Ocean, ensure that commercial activity followed approved environmental practices and require polluters to pay for clean-up efforts. Obviously, such a diplomatic endeavour would be more daunting as it would require multi-layered negotiations among a variety of regional and sub-national actors, which could be lengthy and with an uncertain outcome.

Again, plurilateral diplomacy could prove the right solution for addressing the issue of sustainable fishery management, as it would allow the Arctic Council to establish flexible partnerships with organizations already engaged in EBM. For example, the Global Environment Facility (GEF), which is the largest public funder of projects to improve the global environment, is already supporting sustainable development initiatives related to climate change and international waters. As a GEF Implementing Agency, UNDP-GEF has been applying the EBM approach to thirteen of the world's Large Marine Ecosystems (LMEs). (UNDP 2012b: 9). Aside from the EBM know-how, UNDP-GEF also has the financial instruments for "promoting science-based, long-term integrated planning and barrier removal to transform markets and create sustainable productive use patterns of coastal and ocean resources" (UNDP 2012a: 6).

On AC side, substantial work has already been done. In 2008, the Arctic Council adopteda working map of 17 designated LMEs in the Arctic Ocean to be used as a framework for ecosystem-based management practices in the Arctic (PAME 2008). The key issue remains, nevertheless, implementation. The reports of AC's working groups could be used to advise national governments about how to integrate EBM practices into national policy instruments, but this approach is likely to 
be fragmentary and asymmetrical. A more effective solution would be to establish PAME as a GEF Operational Focal Point (GEF 2012) for coordinating ecosystem sustainability in the Arctic in an integrated manner. This would imply AC would be closely involved in endorsing project proposals that are consistent with national plans and priorities and in facilitating EBM coordination, assessment, integration, and consultation at the country level.

The UNDP/GEF plurilateral connection would also help enhance the AC status of permanent participants and NGO observers. Indigenous organizations already serve as "respected partners in research" (Arctic Council 2011: 27) in the Arctic Council Working Groups Observer-NGOs also influence AC decision-making by and substantially contributing to research. The World Wide Fund for Nature (WWF) is behind the first concrete proposal for an Arctic treaty and it has been closely involved in a variety of research projects aiming at combating threats to the Arctic and preserving its rich biodiversity in a sustainable way (WWF 2013). By adding a new layer of specialized involvement for permanent participants and NGO observers, the UNDP/GEF plurilateral connection thus help create new structures of "collective acting", power exchange and political agency (Tennberg 2010: 269) for non-state AC members.

The plurilateral connection between the Arctic Council and UNDP/GEF would therefore present several important advantages. First, it would eliminate the need for a new comprehensive legal regime in the Arctic, which is opposed by all Arctic states, by shifting the diplomatic agenda from top-down regulatory codification to bottom-up EBM project coordination and implementation. Second, it would create a structure of incentives for AC members to engage in EBM practices by drawing on UNDP/GEF knowledge and financial capacity. Third, the partnership would be sufficiently flexible to allow various configurations of Arctic and non-Arctic states to work together depending on their geographical proximity to the 17 designated Arctic LMEs. Fourth, AC 
transparent monitoring and coordination of EBM projects would help to gradually bridge regulatory asymmetries among AC members. Fifth, it would reinforce the political agency of permanent participants and NGO observers within the AC institutional structure. 


\section{CONCLUSION}

The Arctic region is undergoing significant climatic transformations, which have the potential to fuel diplomatic tensions among regional actors over natural resources, navigation rights, and fishery management. At the heart of the issue lies a triple governance gap informed by the lack of institutional authority of the Arctic Council to address the rising challenges, the weakness of the legal framework that covers Arctic matters, and the low level of political commitment of AC members to extend the legal mandate of the Council and strengthen its institutional structure respectively. The article has argued that a plurilateral diplomatic approach could close these governance gaps in three ways. First, the AC-NATO plurilateral connection could prevent the militarization of the Arctic; second, the AC-IMO partnership could improve the safety and freedom of navigation in the Arctic, and third, the AC-UNDP/GEF diplomatic collaboration could facilitate policy coordination among regional actors on matters pertaining to sustainable fishery management.

The plurilateral "turn" discussed in this article advances the debate regarding the Arctic governance architecture, by explaining not only what kind of institutional regime is actually needed in the Arctic (e.g., one that links AC to NATO, IMO and UNDP/GEF), but also how to make it work. For example, Arctic officials would be better off addressing first the least controversial plurilateral connections such as IMO and UNDP/GEF, and approaching NATO only in the second stage. The distributional impact of plurilateral agreements must be also carefully taken into account. US, Russia, China and the EU need to be closely involved in the design of the plurilateral complex as these actors have currently the capacity to engage in bilateral or multilateral negotiations that can diplomatically marginalize AC. Finally, the three plurilateral connections must complement not duplicate or undermine existing legal regimes by offering a higher degree of policy specialization in contested areas of governance. NATO would provide, for instance, counsel on technical matters 
involving the security of the high-seas, IMO would allow AC to take a more active part in shaping future protocols concerning the freedom of navigation in the Arctic and the prevention of marine pollution, while UNDP/GEF would help create a structure of incentives for AC members to engage in EBM practices by drawing on UNDP/GEF knowledge and financial capacity.

Plurilateral diplomacy also makes two important contributions to the literature on global governance. On the one hand, it explains how governance gaps could be closed in a manner that does not require extensive institutional frameworks or rigid legal mandates, but a flexible "web of contracts" informed by overlapping memberships and cross-cutting interests. Conventional methods of addressing global governance gaps - multilateralism and bilateralism -, are being increasingly outpaced by the complexity and urgency of the $21^{\text {st }}$ century governance challenges. Multilateral conventions now take decades of negotiations (see the case of the UNFCCC or the WTO Doha Development Round) and have uncertain results due to problems of implementation. While being a more agile instrument of international negotiations, bilateralism is nevertheless ill-equipped for tackling complex issues involving multiple actors and it generally favours the strongest parties at the table. This is not to say that multilateralism and bilateralism have no place in the future of global governance, but rather that $21^{\text {st }}$ problems require $21^{\text {st }}$ century solutions emphasizing flexibility, effectiveness, and quick reaction. Plurilateral diplomacy fulfils well these requirements and hence it has much to offer to diplomats and policy-makers. 


\section{Bibliography:}

Arctic Council. 1996. Declaration on the Establishment of the Arctic Council, Sep 191996 [cited Dec 12 2012]. Available from http://www.arcticcouncil.org/index.php/en/about/documents/file/13-ottawa-declaration. 2008. Ilulissat Declaration, May 282008 [cited Jan 2 2013]. Available from http://www.oceanlaw.org/downloads/arctic/Ilulissat_Declaration.pdf.

2011. Senior Arctic Officials (SAO) Report to Ministers, Nuuk, Greenland. Sustainable Development Working Group, May 2011 [cited Mat 28 2013]. Available from http://www.arctic-council.org/index.php/en/about/documents/category/20-main-documentsfrom-nuuk.

- 2012a. Observers 2012a [cited Dec 12 2012]. Available from http://www.arcticcouncil.org/index.php/en/about-us/partners-links.

—. 2012b. Working Groups 2012b [cited Mar 18 2013]. Available from http://www.arcticcouncil.org/index.php/en/about-us/working-groups.

Arctic Governance Project. 2010. Arctic Governance in an Era of Transformative Change: Critical Questions, Governance Principles, Ways Forward 2010 [cited Mar 13 2013]. Available from http://www.arcticgovernance.org/agp-report-and-action-agenda.156784.en.html.

Bayne, Nicholas, and Stephen Woolcock. 2011. "What is Economic Diplomacy?" In The New Economic Diplomacy : Decision-Making and Negotiation in International Economic Relations, edited by Nicholas Bayne and Stephen Woolcock, 1-15. Farnham, Surrey ; Burlington, VT: Ashgate.

BBC. 2009. Denmark plans forces for Arctic, July 162009 [cited Dec 17 2012]. Available from http://news.bbc.co.uk/1/hi/world/europe/8154181.stm.

Berner, Jim, Carolyn Symon, Lelani Arris, O. W. Heal, Arctic Climate Impact Assessment., National Science Foundation (U.S.), and United States. National Oceanic and Atmospheric Administration. 2005. Arctic climate impact assessment. Cambridge; New York, N.Y.: Cambridge University Press.

Bjola, Corneliu. 2002. "NATO enlargement between promises and reality: Cooperation and stability in Central and Eastern Europe." Southeast European Politics no. 3 (2-3):127-153.

Blanco-Bazán, Agustín. 2009. "Specific Regulations for Shipping and Environmental Protection in the Arctic: The Work of the International Maritime Organization." The International Journal of Marine and Coastal Law no. 24 (2):381-386.

Borgerson, S. G. 2008. "Arctic meltdown - The economic and security implications of global warming." Foreign Affairs no. 87 (2):63-77.

Bush, George W. 2009. NSPD-66 / HSPD-25. White House, Jan 92009 [cited Dec 17 2012].

CBCNews. 2010. Canada-Russia Arctic tensions rise, Mar 172010 [cited Mar 18 2013]. Available from http://www.cbc.ca/news/world/story/2010/03/17/arctic-russia017.html. 
Cerny, Philip. G. 1993. "Plurilateralism - Structural Differentiation and Functional Conflict in the Post-Cold-War World-Order (Vol 22, Pg 43, 1993)." Millennium-Journal of International Studies no. 22 (2):R4-R4.

Chistyakov, V. 2010. Arctic does not need NATO presence - Lavrov. RIA Novosti, Sept 162010 [cited Dec 17 2012]. Available from http://en.rian.ru/world/20100916/160610966.html.

Clark, Campbell. 2012. Harper's tough talk on the Arctic less stern in private. Globe \& Mail, Aug 24 2012 [cited Dec 17 2012]. Available from http://m.theglobeandmail.com/news/politics/harpers-tough-talk-on-the-arctic-less-stern-inprivate/article579749/? service $=$ mobile.

Conley, Heather A., and Jamie Kraut. 2010. U.S. Strategic Interests in the Arctic: An Assessment of Current Challenges and New Opportunities for Cooperation. Center for Strategic and International Studies, April 2010 [cited Dec 1 2012]. Available from http://csis.org/files/publication/100426_Conley_USStrategicInterests_Web.pdf.

Debabov, Dmitriy. 2011. Russia to Field First Arctic Brigade in 2015. RIA Novosti, Feb 212011 [cited Dec 17 2012]. Available from http://en.rian.ru/military_news/20120221/171440711.html.

Eger, Karl Magnus 2011. Marine Traffic in the Arctic. Norwegian Mapping Authority, Aug 162011 [cited 2012 Dec 8]. Available from http://www.iho.int/mtg docs/rhc/ArHC/ArHC2/ARHC204C_Marine_Traffic_in_the_Arctic_2011.pdf.

Eide, Lars Ingolf, Magnus Eide, and Øyvind Endresen. 2010. Shipping across the Arctic Ocean: A feasible option in 2030-2050 as a result of global warming? DNV 2010 [cited Dec 8 2012]. Available from http://www.dnv.com/binaries/shipping\%20across\%20the\%20arctic\%20ocean\%20position\%2 0paper_tcm4-434419.pdf.

GEF. 2012. Focal Points 2012 [cited Jan 3 2013]. Available from http://www.thegef.org/gef/focal_points.

George, Jane. 2012. Arctic Council officials call for reinstatement of Russian indigenous org. Nunatsiaq News, Nov 152012 [cited Mar 13 2013]. Available from http://www.nunatsiaqonline.ca/stories/article/65674arctic_council_calls_for_russian_indigen ous_orgs return/.

Glasby, G.P., and Yu.L. Voytekhovsky. 2009. Arctic Russia: Minerals and Mineral Resources.

Geochemical News, July 2009 [cited Dec 6 2012]. Available from http://www.geochemsoc.org/publications/geochemicalnews/gn140jul09/arcticrussiamineralsa $\underline{\text { ndmin.htm. }}$.

Government of Canada. 2009. Canada's Northern Strategy: Our North, Our Heritage, Our Future July 2009 [cited Dec 17 2012]. Available from http://www.northernstrategy.gc.ca/cns/cns.pdf.

Hoel, Alf Håkon 2009. "Do We Need a New Legal Regime for the Arctic Ocean?" The International Journal of Marine and Coastal Law no. 24 (2):443-456. 
Humpert, Malte, and Andreas Raspotnik. 2012. The Future of Arctic Shipping Port Technology International, Nov 202012 [cited Dec 8 2012]. Available from

http://www.porttechnology.org/images/uploads/technical_papers/The_future_of_Arctic_ship ping.pdf.

IMO. 2011. About IMO 2011 [cited Dec 20 2012]. Available from http://www.imo.org/About/Pages/Default.aspx.

- 2013. Development of an international code of safety for ships operating in polar waters 2013 [cited Apr 30 2013]. Available from http://www.imo.org/MediaCentre/HotTopics/polar/Pages/default.aspx.

IPCC. 2007. Fourth Assessment Report 2007 [cited Jan 27 2012]. Available from http://www.ipcc.ch/pdf/assessment-report/ar4/syr/ar4_syr.pdf.

Jares, Vladimir. 2009. "The Continental Shelf Beyond 200 Nautical Miles: The Work of the Commission on the Limits of the Continental Shelf and the Arctic." Vanderbilt Journal of Transnational Law no. 42:1265-1305.

Jones, Meirion, and Susan Watts. 2011. Wikileaks cables show race to carve up Arctic BBC Newsnight, May 122011 [cited Mar 13 2013]. Available from http://news.bbc.co.uk/1/hi/programmes/newsnight/9483790.stm.

Kenneth J. Bird et al. 2008. Circum-Arctic Resource Appraisal: Estimates of Undiscovered Oil and Gas North of the Arctic Circle. United States Geological Survey, Fact Sheet 2008-3049 2008 [cited Dec 6 2012]. Available from http://pubs.usgs.gov/fs/2008/3049/fs2008-3049.pdf.

Kilner, James. 2008. Medvedev wants Russia to set Arctic seabed borders. Reuters, Sept 172008 [cited Dec 17 2012]. Available from http://www.reuters.com/article/2008/09/17/us-russiaarctic-idUSLH46436320080917.

Koivurova, Timo. 2010. "Limits and possibilities of the Arctic Council in a rapidly changing scene of Arctic governance." Polar Record no. 46 (02):146-156.

Leitzell, Katherine. 2011. When will the Arctic lose its sea ice? National Snow and Ice Data Center, May 32011 [cited Dec 3 2012]. Available from http://nsidc.org/icelights/2011/05/03/whenwill-the-arctic-lose-its-sea-ice/.

Lindholt, Lars. 2006. Arctic natural resources in a global perspective. In The Economy of the North, edited by Solveig Glomsrød and Iulie Aslaksen. Oslo: Statistics Norway.

Macalister, Terry. 2013. Greenland government falls as voters send warning to mining companies. Guardian, Mar 152013 [cited Mar 18 2013]. Available from http://www.guardian.co.uk/world/2013/mar/15/greenland-government-oil-miningresources?CMP=twt_gu.

Mitzen, Jennifer. 2010. "Governing Together: Global Governance as Collective Intention." In Arguing Global Governance: Agency, Lifeworld and Shared Reasoning, edited by Corneliu Bjola and Markus Kornprobst, 52-66. Milton Park, Abingdon, Oxon ; New York: Routledge.

NATO. 2013. Partnerships: a cooperative approach to security Mar 202013 [cited Mar 282013 ]. Available from http://www.nato.int/cps/en/natolive/topics_84336.htm? 
Norwegian Armed Forces. 2012. Cold Response 2012: Participants March 2012 [cited Dec 17 2012]. Available from http://mil.no/excercises/coldresponse2012/Pages/participants.aspx.

Norwegian Ministry of Foreign Affairs. 2011. The High North: Visions and Strategies, Nov 182011 [cited Dec 17 2012]. Available from http://www.regjeringen.no/upload/UD/Vedlegg/Nordomr\%c3\%a5dene/UD_nordomrodene_E N_web.pdf.

PAME. 2008. 2008 [cited Jan 3 2013]. Available from http://www.pame.is/arctic-large-marineecosystems-lme-s.

Reichert, Christian. 2009. "Determination of the Outer Continental Shelf Limits and the Role of the Commission on the Limits of the Continental Shelf." The International Journal of Marine and Coastal Law no. 24:387-399

Rincon, Paul. 2012. Record minimum for Arctic sea ice. BBC, Sept 192012 [cited Dec 4 2012]. Available from http://www.bbc.co.uk/news/science-environment-19652329.

Rodrigue, Jean-Paul. 2012. Polar Shipping Routes. Dept. of Global Studies \& Geography , Hofstra University 2012 [cited Dec 8 2012]. Available from http://people.hofstra.edu/geotrans/eng/ch1en/conc1en/polarroutes.html.

Rosenthal, Elisabeth. 2012. Race Is On as Ice Melt Reveals Arctic Treasures. New York Times, Sept 182012 [cited Mar 13 2013]. Available from http://www.nytimes.com/2012/09/19/science/earth/arctic-resources-exposed-by-warming-setoff-competition.html?pagewanted=all\&_r=0.

Saner, Raymond. 2012. Plurilateral Agreements: Key to solving impasse of WTO/Doha Round and basis for future trade agreements within the WTO contex, April 2012 [cited Mar 28 2013]. Available from http://www.csend.org/site1.5/images/files/CSEND_Policy_Brief_Nr_7_Plurilaterals_April_2012_1.pdf.

Siron, R., K. Sherman, H. R. Skjoldal, and E. Hiltz. 2008. "Ecosystem-Based Management in the Arctic Ocean: A Multi-Level Spatial Approach." Arctic no. 61:86-102.

Stokke, Olav Schram. 2011. "Environmental security in the Arctic The case for multilevel governance." International Journal no. 66 (4):835-848.

Tennberg, Monica. 2010. "Indigenous peoples as international political actors: a summary." Polar Record no. 46 (238):264-270.

U.S. Geological Survey. 2008. 90 Billion Barrels of Oil and 1,670 Trillion Cubic Feet of Natural Gas Assessed in the Arctic. U.S. Department of the Interior, July 232008 [cited Dec 3 2012]. Available from http://www.usgs.gov/newsroom/article.asp?ID=1980.

UNDP. 2012a. Catalysing Ocean Finance: Transforming Markets to Restore and Protect the Global Ocean, Sept 2012a [cited Jan 3 2013]. Available from http://www.undp.org/content/dam/undp/library/Environment\%20and\%20Energy/Water\%20a nd\%20Ocean\%20Governance/Oceans\%20and\%20Coastal\%20Area\%20Governance/Catalysi ng-Ocean-Finance-Vol-I.pdf. 
2012b. International Waters - Delivering Results, June 15 2012b [cited Jan 3 2013].

Available from

http://www.undp.org/content/dam/undp/library/Environment\%20and\%20Energy/Water\%20a nd\%200cean\%20Governance/IW_DeliveringResults-2012.pdf.

United Nations. 1982. United Nations Convention on the Law of the Sea, Dec 101982 [cited Dec 6 2012]. Available from

http://www.un.org/Depts/los/convention_agreements/texts/unclos/closindx.htm.

US Department of Energy. 2012. Arctic Oil and Natural Gas Potential, Jan 52012 [cited Dec 4 2012]. Available from http://www.eia.gov/oog/info/twip/twiparch/111221/twipprint.html.

US Navy Department. 2009. U.S. Navy Arctic Roadmap, Nov 102009 [cited Dec 17 2012]. Available from http://www.navy.mil/navydata/documents/USN_artic_roadmap.pdf.

WWF. 2013. Global Arctic Programme 2013 [cited Mar 28 2013]. Available from http://awsassets.panda.org/downloads/global_arctic_programme_factsheet_2012_01_letter_e nglish.pdf.

Young, Oran R. 2012. "Building an international regime complex for the Arctic: current status and next steps." The Polar Journal no. 2 (2):391-407.

Zartman, I. William. 1994. International multilateral negotiation : approaches to the management of complexity. 1st ed. San Francisco: Jossey-Bass. 